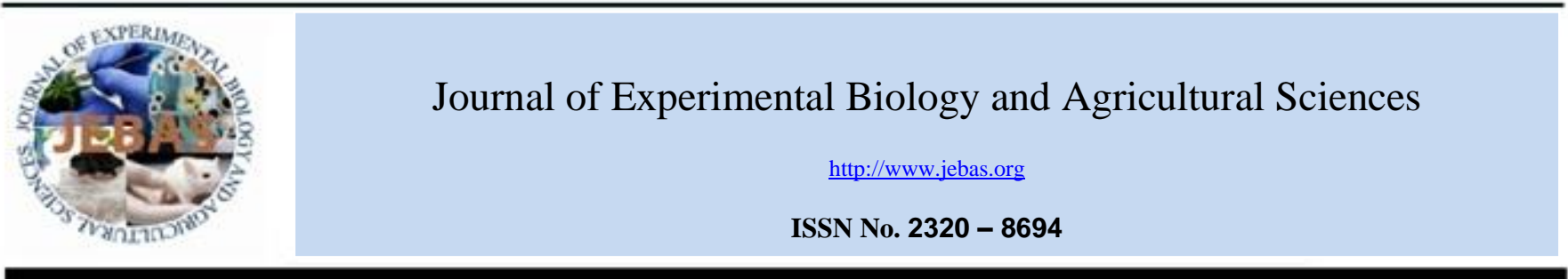

\title{
EVALUATING DROUGHT RESISTANT WHEAT CULTIVARS BASED ON STEM ANATOMICAL CHARACTERISTICS
}

\author{
Maryam ABBASI $^{{ }^{*}}$, Elham FAGHANI ${ }^{2}$, Ali HOSSIEN KHANI ${ }^{3}$, Mohammad Hosein RAZZAGHI ${ }^{4}$ \\ ${ }^{1}$ Department of Biology, College of Basic Sciences, Central Tehran Branch, Islamic Azad University, Tehran, Iran \\ ${ }^{2}$ Cotton research institute agricultural research, Education and extension organization (areoo), Gorgan, Iran \\ ${ }^{3}$ Department of Cellular and Molecular Biology, Young Researchers and Elite Club, Central Tehran Branch, Islamic Azad University, Tehran, Iran \\ ${ }^{4}$ Department of a Agricultural engineering research, Golestan agriculture and natural resources, agricultural research , education and extension organization (areeo), \\ Gorgan, Iran.
}

Received - February 13, 2017; Revision - May 21, 2017; Accepted - June 07, 2017

Available Online - June 30, 2017

DOI: http://dx.doi.org/10.18006/2017.5(3).332.340

\section{KEYWORDS}

Triticum aestivum

Anatomy

Drought resistance

Iran

\section{ABSTRACT}

Water stressed have vital effect on the various anatomical, physiological and bio-chemical processes, which are controlled by genetic and prevailing environment. In present study, 25 wheat (Triticum aestivum L.) cultivars, which have been released over 40 years in Iran, were evaluated in terms of stem physiological and anatomical changes at Iran Agricultural Research Station. During growing season data were collected and finally crop was harvested in June and various anatomical aspects like Thickness of stem (TS), Thickness of fiber (TF), Tangential dimension of collenchymas cells (TDC), Tangential dimension of vascular bundle (TDVB), Radial dimension of vascular bundle (RDVB), Radial dimension of big xylem vessel (RDBXV), Tangential dimension of phloem bundle (TDPB), Distance between vascular bundle to Epidermis (DBVBE), Thickness of epidermal cell (TE) that are integral part of drought resistance were studied. Predominantly drought resistant genotypes were recorded with anatomical aspects which play major role in imparting drought resistance. Among the studied 25 genotypes, genotype number 7, 21 and 25 showed maximum drought resistance characteristics collectively and these can be used as parent cultivars for future breeding programs.
* Corresponding author

E-mail: mar.abasi@iauctb.ac.ir (Maryam ABBASI)

Peer review under responsibility of Journal of Experimental Biology and Agricultural Sciences.

Production and Hosting by Horizon Publisher India [HPI] (http://www.horizonpublisherindia.in/).

All rights reserved.
All the article published by Journal of Experimental Biology and Agricultural Sciences is licensed under a Creative Commons Attribution-NonCommercial 4.0 International License Based on a work at www.jebas.org.

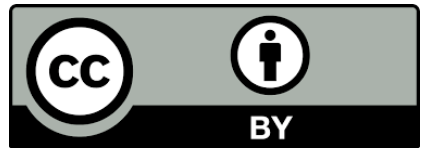




\section{Introduction}

Drought is one of the most limiting abiotic stresses which affecting the yield and yield stability in various agriculture system (Boyer, 1982; Ludlow \& Muchow, 1990; Teulat et al., 2001; Abebe et al., 2003; Zhang et al., 2006). Among various yield deciding factors, drought became a major threat form past few years when no rainfall occurs in most part of the world especially during winter (Kazmi et al., 2003). Throughout the world about one-third of the agricultural production area faced less rain fall problem and among these half of area have less than 250 millimeters annual rainfall. Generally, arid and semi-arid regions cover 44 million $\mathrm{km}^{2}$ of Earth's surface and approximately $39 \%$ of this area is classified as arid regions (Sajjad et al., 2011).

Iran is located in the world's desert belt, and most of its geographical area is considered as the arid and semiarid region. Average rainfall in the country is about $250 \mathrm{~mm}$ which is one third of average rainfall in the world, while 1.2 percent of the world's land is allocated to Iran. Development of higher yield given varieties under drought conditions are the main concern of plant breeders. Drought indices provide a measure of drought based yield loss under drought-conditions as compared to normal conditions have been used for screening drought-tolerant genotypes (Mitra, 2001). Wheat grows as a rain-fed crop in semiarid areas, where large fluctuations occurred in amount and frequency of production and insufficient water supply is the primary limitation (Ashraf \& Harris, 2005). The ability of wheat cultivars to perform well under variable rainfall and water stressed environments is an important trait for stability of production under drought stress conditions (Pirayvatlov, 2001). Also, Blum (1996) suggested that genotypes with high yield may not be stress resistant, so increasing the yield in these genotypes may be solely due to their high potential yield, and not due to stress resistance mechanism. However, Sloane believed that yield selection in the absence of drought is an effective method to improve yield in dry areas (Sloane et al., 1990).

During past few decades, study on different species of family Poaceae has expanded rapidly to development wheat genetic through using intra and inter genetic hybrids (Mujeeb-Kazi et al., 2008; Ogbonnaya et al., 2013). Genetic variation leads to the identification of suitable parents for future wheat breeding programs (Bahar et al., 2008; Kahrizi et al., 2010). Sajjad et al. (2011) reported changes in wheat yield due to interaction between genetic and environment. According to Waldern (1982), seven-day drought stress along with high temperature could reduce wheat yield up to $50 \%$.

In addition to this, various researchers have been reported that plant anatomical features such as leaf and stem anatomy also have considerable effect on the increasing water stress tolerance in wheat crop (Jones et al. 1980; Venora \& Calcagno, 1991). Similarly, cuticle thickness, stomatal frequency (Rebetzke et al., 2008), length of parenchyma cells (Bohnert \& Jensen, 1996), movement and sensitivity (Drake et al., 2013) are also some anatomical characteristics which believed to be useful for developing water stress tolerant genotypes. Future progress in improving drought resistance may help in focusing on specific traits which will help in improving either crop water use efficiency or harvest index. The current study was aimed to select the most appropriate wheat cultivars to be grown in dry lands using stem anatomical traits.

\section{Materials and Methods}

\subsection{Plant materials}

In this study, 25 wheat cultivars, which have been released over 40 years, were evaluated in terms of physiological and anatomical stem aspects at Gorgan (Iran) Agricultural Research Station. Name, origin and pedigree of genotypes of T. aestivum was shown in Table 1. The field was prepared using moldboard plough and disk. The plots were $1 \times 6.5 \mathrm{~m}$ consist of 5 rows. The wheat seeds were sown in early January based on seed weight at 350 seeds per square meter. Chemical fertilizers were applied according to the soil analysis results. The experimental design was a randomized complete block design with thee replicates. During growing season data were collected and finally crop was harvested in June.

\subsection{Anatomical aspects}

Stem anatomical characters were studied from the transverse sections of the stem $(10 \mathrm{~cm}$ from base), five replications per cultivar were fixed in acetic-alcohol fixative ( 3 parts of $70 \%$ ethyl alcohol and 1 part glacial acetic acid). Thin transverse sections of preserved stem were cut with help of razors and stained with safranin and fast green stain and examined under microscope. Each section was photographed at $40 \mathrm{X}$ magnification with a digital camera connected to a microscope and were measured with image analysis software (Scion Image, USA). Various anatomical measurements like Thickness of stem (TS), Thickness of fiber (TF), Tangential dimension of collenchymas cells (TC), Tangential dimension of vascular bundle (TDVB), Radial dimension of vascular bundle (RDVB), Radial dimension of big xylem vessel (RDBXV), Tangential dimension of phloem bundle (TDPB), Distance between vascular bundle to Epidermis (DBVBE), Thickness of epidermal cell (TE)were studied (Adhikary et al., 2007). Vessels were not exactly circular, diameter was calculated as the mean of maximum and minimum inside (lumen) diameters.

\section{Results and Discussion}

\subsection{Thickness of stem (TS)}

Distance between epidermis and hollow pith was considered as stem thickness. Results of study revealed the improvement in photosynthetically active parenchymatus cells as compared to control (Figure 1). Maximum stem width was observed in genotypes number 7 and 10 (Figure 11G) and (Figure 12J), it was followed by the accession, 16 and 20. Among the texted 25 wheat accessions, minimum stem width was reported from the wheat genotype 3,17 
Table 1 Name, origin and pedigree of the various genotypes of $T$. aestivum $\mathrm{L}$.

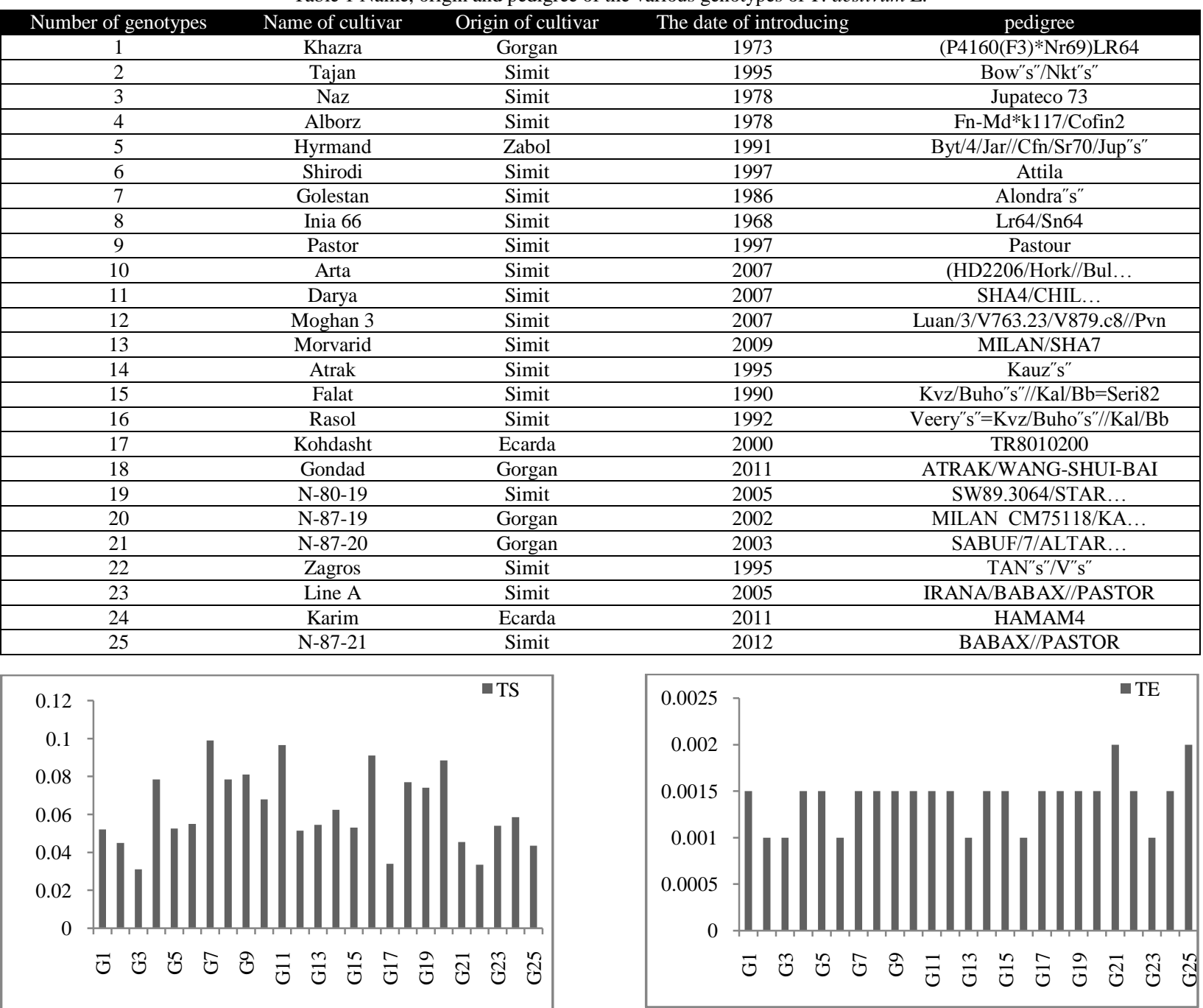

Figure 1 Thickness of stem in wheat cultivars

and 22 (Figure 10C, Figure 14Q, Figure 15V). According to Kulkarni et al. (2008) this increase in photosynthetically active stem tissues across the section is an index of increase drought resistance. Further, it was believed that the increased in the amount of photosynthetic parenchyma may increase the water use efficiency of plants under a water stress situation (Kulkarni et al., 2008).

\subsection{Thickness of epidermis cell (TE)}

Increased in the width of epidermis is a desirable phenomenon of wheat genotype because it decreases the rate of transpiration. In drought resistant genotypes width of epidermis was found more than the drought tolerance genotypes. During this study (Figure 2), maximum epidermal thickness was reported from the genotypes 21 and 25 respectively (Figure 15U, Figure 15Y) whereas other cultivars were not showing any significant differences in the thickness of epidermal cells. Results are in accordance with the findings of Kulkarni et al. (2008) those have reported higher epidermal cell size in xerophytes plants.
Figure 2 Thickness of epidermis in wheat cultivars

\subsection{Thickness of fiber (TF)}

In wheat stem, sclerenchymatus tissues or fiber are most abundant and support vascular bundles. These mechanical tissues could play an important role in reduction of the rate of transpiration. Although, it is still a matter of controversy that whether this reduction in the rate of transpiration is because of fiber thickness or something else. As shown in figure 3, the maximum fiber width was observed in 21 genotype (Figure $15 \mathrm{U}$ ). In addition, genotype number 4, 7 and 19 showed minimum fiber width as compared to the other genotypes ( Figure 10D, Figure11G and Figure 14S). Fibers and dermal tissues together provide rigidity and protection from tissue degradation, water loss, microbes and insects etc. (Farooq, 2009). Further, Zhang et al. (2006) reported that over expression of pyrophosphatase gene (AVP1) increased fiber yield in dry land field conditions and improve drought tolerance. Measurements of Sclerenchyma tissue in terms of the overall stem rigidity provide only an estimate of the amount of the mechanical tissues in a stem and leaf (Abbasi et. al, 2016). 


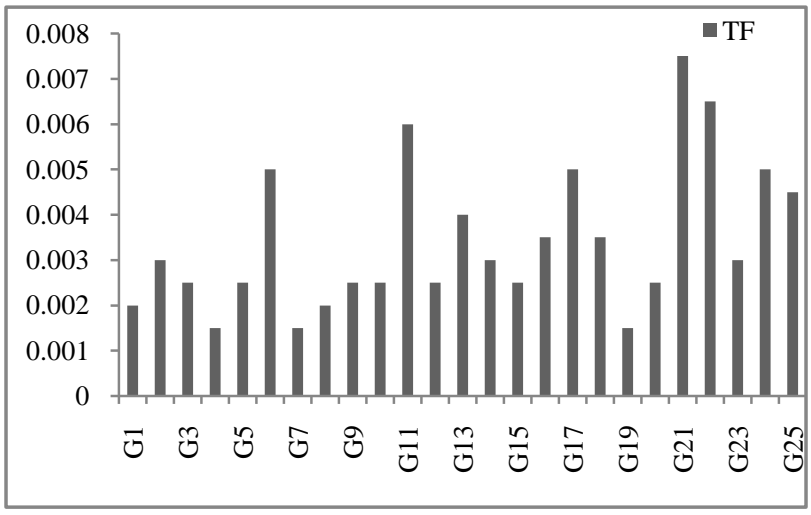

Figure 3 Thickness of fiber in wheat cultivars

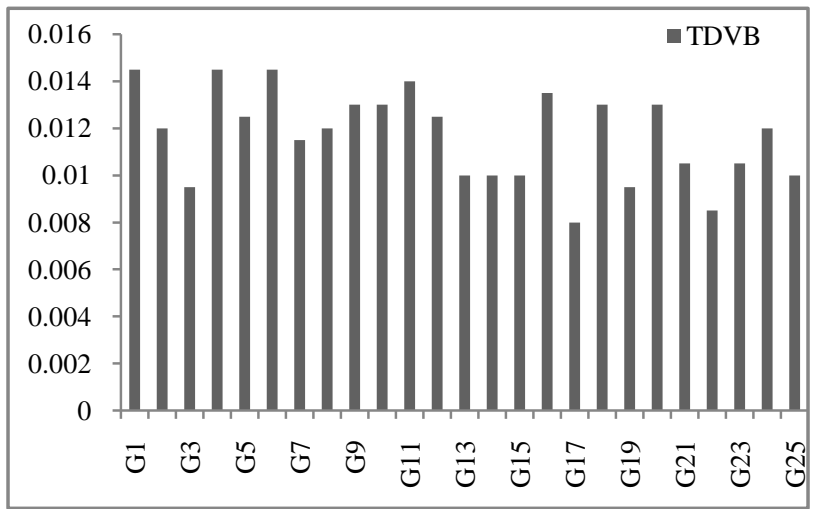

Figure 5 Tangential dimension of vascular bundle

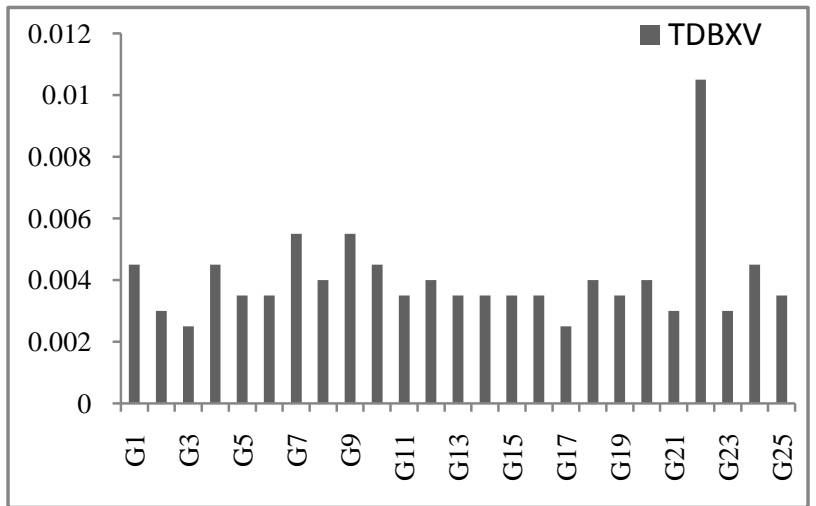

Figure 7 Tangential dimension of big xylem bundle

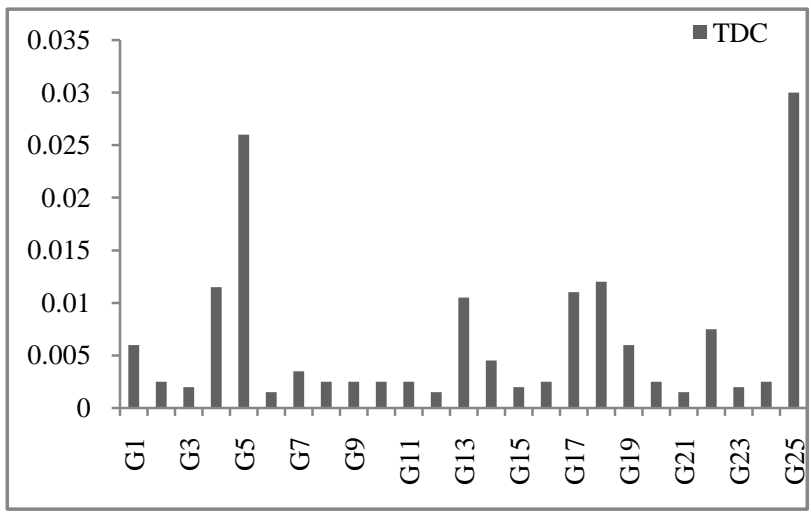

Figure 4 Tangential dimension of collenchymas tissue

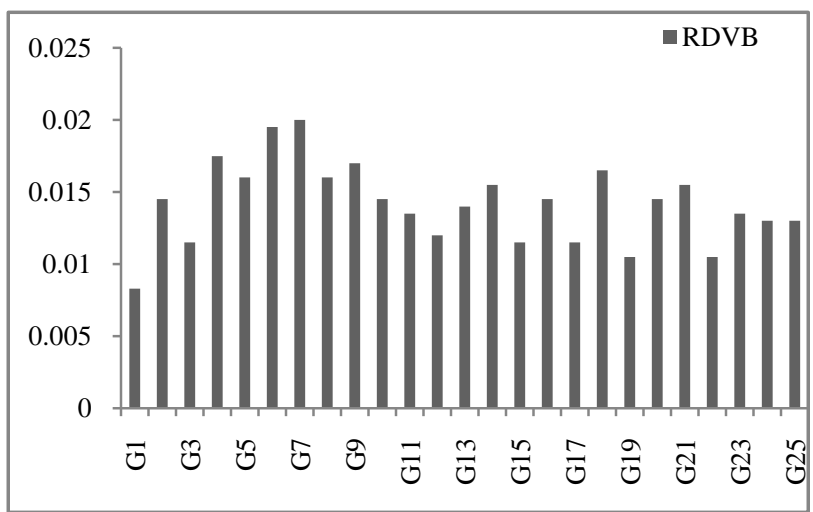

Figure 6 Radial dimension of vascular bundle

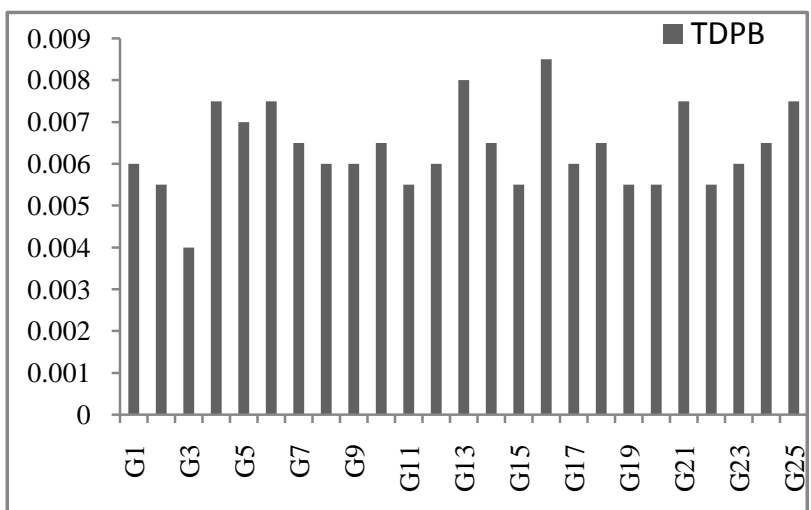

Figure 8 Tangential dimension of phloem 


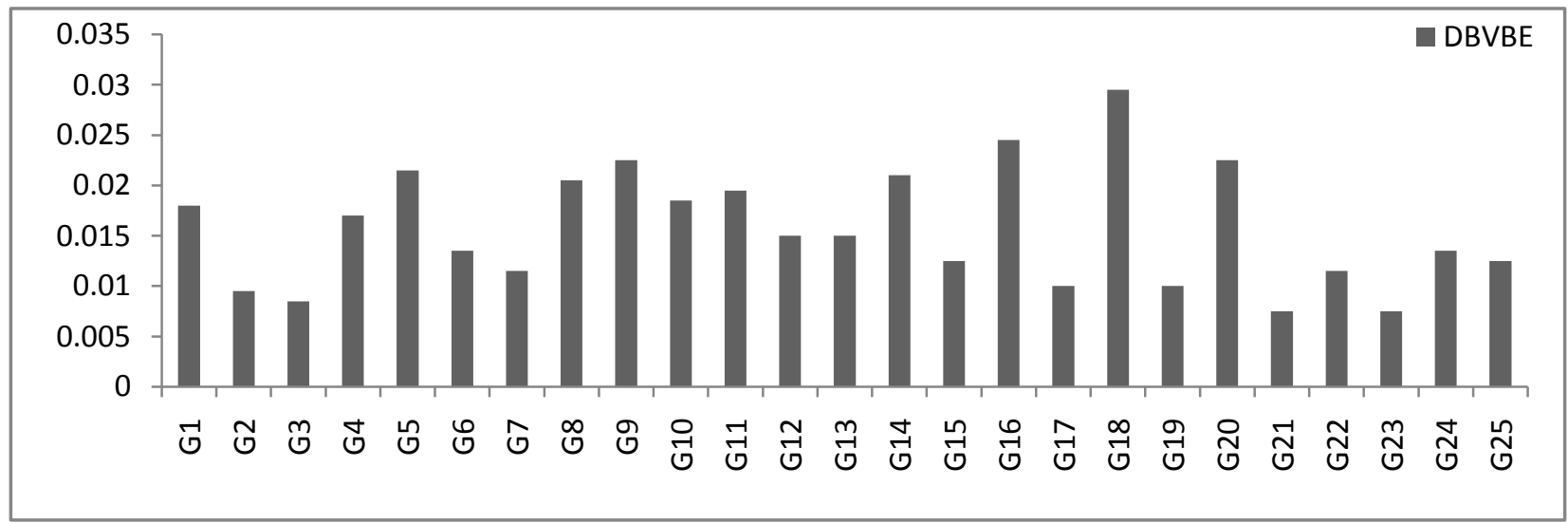

Figure 9 distance between vascular bundle to epidermis
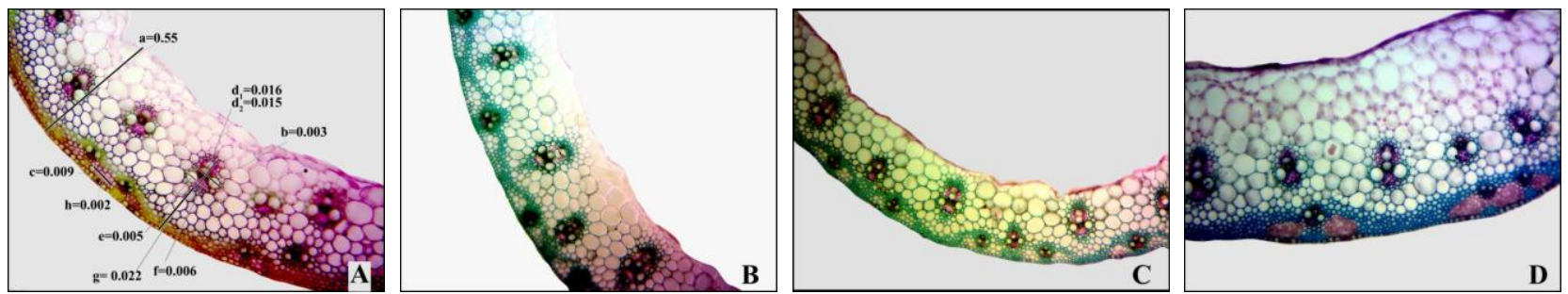

Figure 10 Transverse sections of stem cultivars. A: G1, B: G2, C: G3, D: G4 $\mathrm{a}=\mathrm{TS}, \mathrm{c}=\mathrm{TDC}, \mathrm{d} 1, \mathrm{~d} 2=$ DVB, $\mathrm{e}=\mathrm{TDBXV}, \mathrm{f}=\mathrm{TDPB}, \mathrm{g}=$ DBVBE, $\mathrm{h}=\mathrm{TE}$
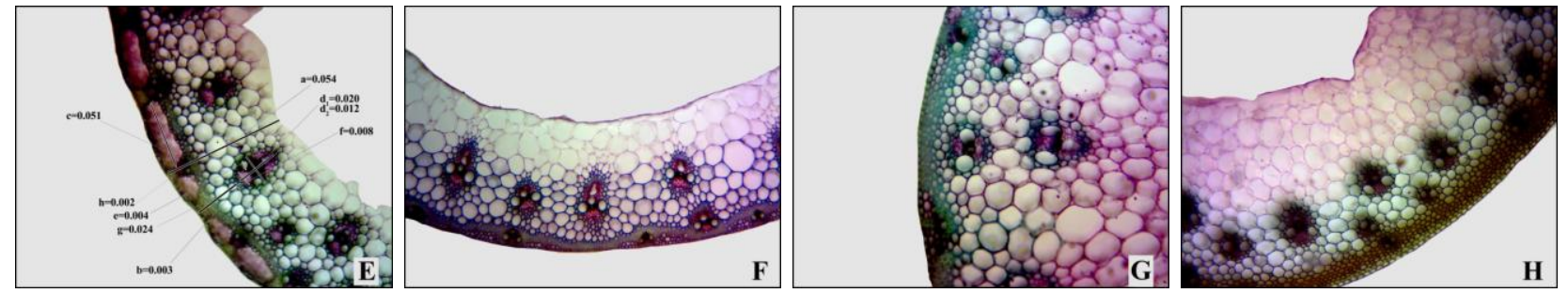

Figure 11 Transverse sections of stem cultivars E: G5, F: G6, G: G7, H: G8 $\mathrm{a}=\mathrm{TS}, \mathrm{c}=\mathrm{TDC}, \mathrm{d} 1, \mathrm{~d} 2=\mathrm{DVB}, \mathrm{e}=\mathrm{TDBXV}, \mathrm{f}=\mathrm{TDPB}, \mathrm{g}=\mathrm{DBVBE}, \mathrm{h}=\mathrm{TE}$
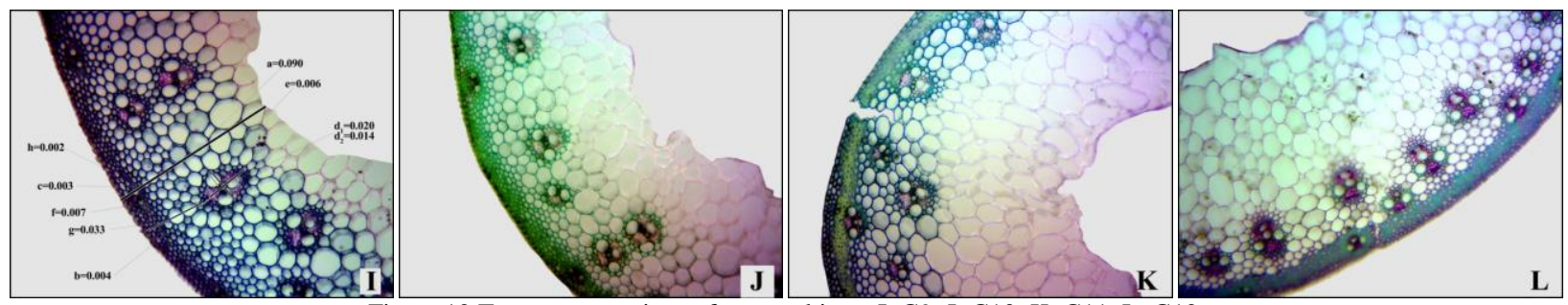

Figure 12 Transverse sections of stem cultivars I: G9, J: G10, K: G11, L: G12

$\mathrm{a}=\mathrm{TS}, \mathrm{c}=\mathrm{TDC}, \mathrm{d} 1, \mathrm{~d} 2=$ DVB, $\mathrm{e}=\mathrm{TDBXV}, \mathrm{f}=\mathrm{TDPB}, \mathrm{g}=$ DBVBE, $\mathrm{h}=\mathrm{TE}$ 

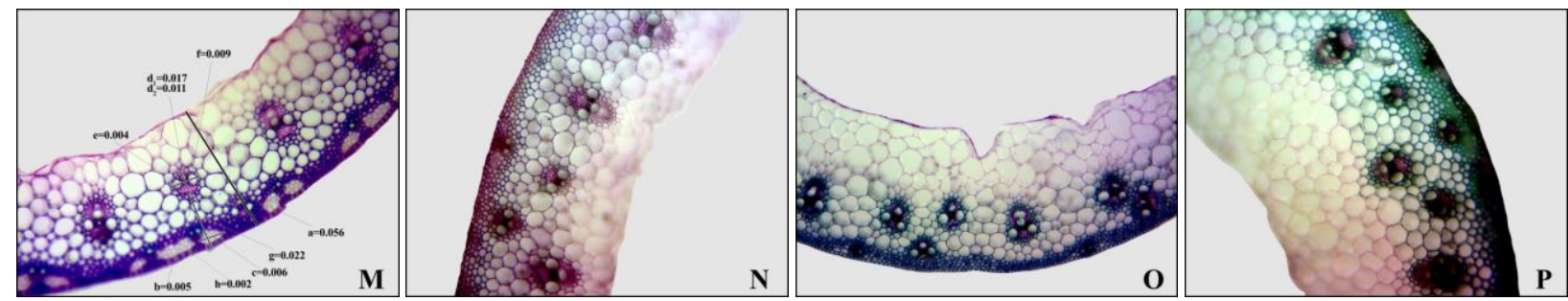

Figure 13 Transverse sections of stem cultivars M: G13, N: G14, 0: G15, P: G16 $\mathrm{a}=\mathrm{TS}, \mathrm{c}=\mathrm{TDC}, \mathrm{d} 1, \mathrm{~d} 2=\mathrm{DVB}, \mathrm{e}=\mathrm{TDBXV}, \mathrm{f}=\mathrm{TDPB}, \mathrm{g}=\mathrm{DBVBE}, \mathrm{h}=\mathrm{TE}$
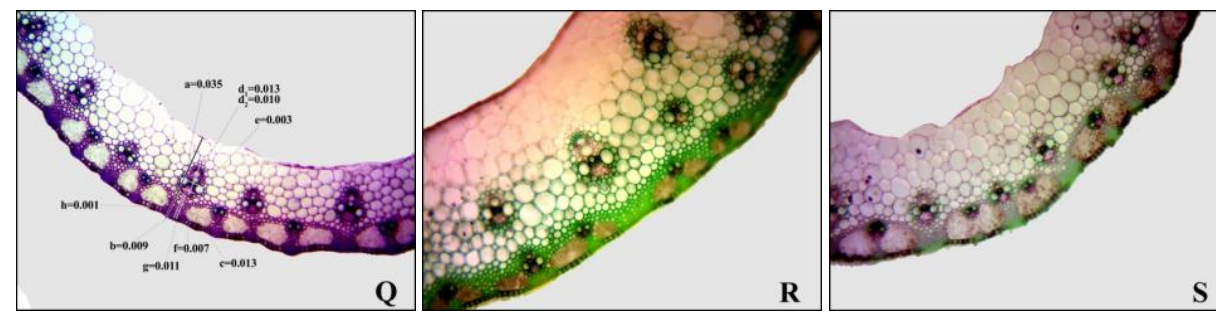

Figure 14 Transverse sections of stem cultivars Q: G17, R: G18, S: G19, T: G20 $\mathrm{a}=\mathrm{TS}, \mathrm{c}=\mathrm{TDC}, \mathrm{d} 1, \mathrm{~d} 2=\mathrm{DVB}, \mathrm{e}=\mathrm{TDBXV}, \mathrm{f}=\mathrm{TDPB}, \mathrm{g}=\mathrm{DBVBE}, \mathrm{h}=\mathrm{TE}$
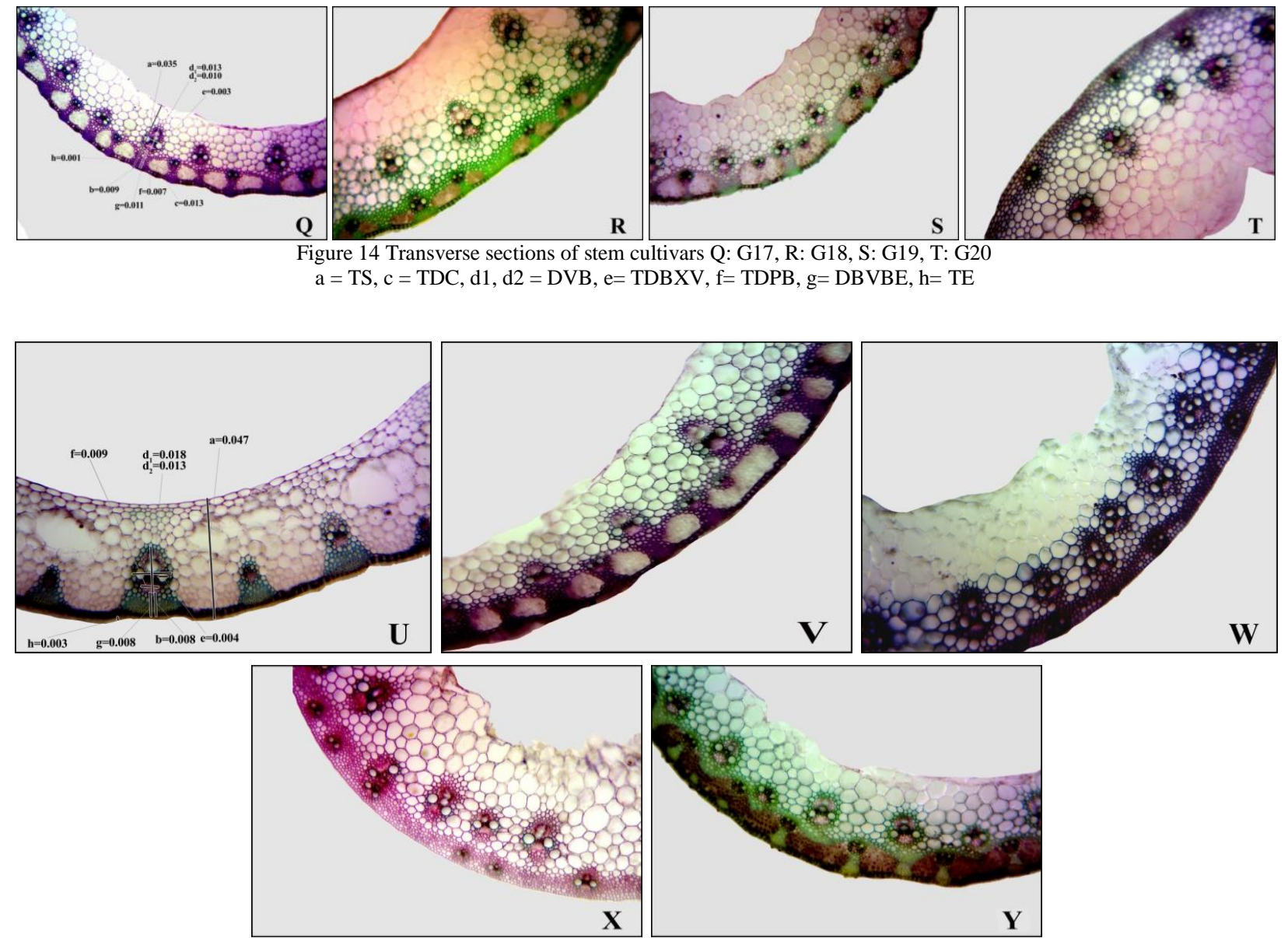

Figure 15 Transverse sections of stem cultivars U: G21, V: G22, W: G23, X: G24, Y: G25 $\mathrm{a}=\mathrm{TS}, \mathrm{c}=$ TDC, $\mathrm{d} 1, \mathrm{~d} 2=$ DVB, $\mathrm{e}=$ TDBXV, $\mathrm{f}=$ TDPB, $\mathrm{g}=$ DBVBE, $\mathrm{h}=\mathrm{TE}$

\subsection{Tangential dimension of collenchymas cells (TDC)}

In this study, a significant difference was reported between various cultivars with relation to collenchymas tissue thickness (tangential dimension of collenchymas cells). Among various tested genotypes (Figure 4), maximum thickness was observed in genotype number 25 (Figure 15Y) and it is at par the genotype number 5 (Figure 11E). While minimum collenchymas tissue thickness was reported from the genotypes number 6, 12 and 21 (Figure 11F, Figure 12L and Figure 15U). Hansen, (2013) suggested that deposition of secondary wall on collenchymas tissues play a crucial role in drought resistance.
3.5 Radial and Tangential dimension of vascular bundle (RDVB) and (TDVB)

Vascular bundles consists xylem and phloem and are supported by sclerenchyma tissue (fibers) in wheat stem. It was reported that number of xylem vessels in stress tolerance genotypes was higher as compared to susceptible genotype. In this study a significant difference was reported in radial and tangential dimension of vascular bundles between various genotypes (Figure 5 and Figure 6). Maximum dimension was observed in genotypes 6 and 7 (Figure 11F, Figure11G) while minimum dimension was observed in genotypes number 1, 19 and 2, respectively (Figure 10A, Figure 
14S, Figure10B). Bigger vascular bundles can improve the stem efficiency under drought stress conditions. According to Kulkarni et al. (2008) higher number of vessels in stem increases the efficiency of translocation along with conductivity and photosynthetic storage which can impart adaptability to drought stress. Blum (2011) discussed genotypic variation for the ability to store and mobilizes carbohydrates for seed filling during terminal moisture stress.

\subsection{Radial dimension of big xylem vessel (RDBXV)}

Xylem vessel diameter is an easy criterion for selection of genotypes for drought tolerance. In this study, different cultivars were showing significant difference in xylem dimension (Figure 7) and maximum diameter was reported from the genotype number 22 while minimum from the genotype number 3 and 17 genotypes, respectively (Figure 10C, Figure 14Q). Assimilate retranslocation is universal trait with intermediate heritability (Sloane et al., 1990). Relatively wide xylem conduits in stem could supply sufficient water to leaves to compensate the water losses. Kulkarni et al. (2008) reported that drought susceptible genotypes of tomato had smaller and less number of xylem vessels whereas resistant genotypes have more xylem vessels with bigger size. On the other hand increasing the xylem diameter in some plant may also beneficial under water stress condition and provide a water reservoir to the plants which used at day times when water demand is high ( Martre \& Durand, 2001, Abbasi et al., 2016).

\subsection{Tangential dimension of phloem bundle (TDPB)}

Result presented in figure 8 revealed that maximum tangential dimension of phloem was reported in genotype 16 and it was followed by the genotypes 13 (Figure 13P, Figure 13M) while the minimum dimension was observed in genotype number 3 (Figure $10 \mathrm{C})$. Further, no significant difference was reported in phloem dimension of genotypes numbers 19 and 20 (Figure 14S, Figure 14T). Larger secondary phloem area is an indication of higher conduction of photosynthesis product. Secondary phloem was found with higher width in drought resistant cultivars stem and this increased the ability of conducting more food material (Kulkarni \& Deshpande 2006). Further, Kulkarni et al. (2008) suggested that higher proportion of phloem and conducting tissues in stem were positively correlated with dry matter production under stress conditions .

\subsection{Distance between vascular bundle to Epidermis (DBVBE)}

Results related to distance between vascular bundle to epidermis are presented in figure 9; these results suggested maximum distance in genotype number 18 (Figure 14G) while it was reported minimum in genotype number 21 and 23 (Figure 15U. 15W). Whereas some cultivars have similar distance between outer vascular bundles to epidermis and these were not significantly different from each others. Kulkarni et al. (2008) revealed that Width of cortex in tomato stem was higher in drought resistant genotypes as compared to susceptible ones.

Result of this study revealed that stem anatomical characteristics can consider as advantageous factors with relation to drought resistance. It is an indication of extra capacity to store food material, which is useful during stress conditions. According to Sloane et al. (1990) yield selection in the absence of drought is an effective method to improve yield in dry areas .

According to the correlation coefficients (Table 2), positive correlation was reported between the stem thickness and radial dimension of vascular bundle (RDVB) which confirms the maximum stem thickness and thicker RDVB in genotype number 7. Therefore, this genotype can be chosen as the best genotype and it can efficiently delivered water and nutrients through the stem under drought conditions. Further, a significant $(p<0.05)$ and positive correlation was reported between the distance of the last bundle to epidermal cells and tangential dimension of vascular bundles. In addition, significant $(\mathrm{p}<0.01)$ and positive correlation was also reported between the distance between the last bundle to epidermal cells and stem thickness.

\section{Conclusion}

Current study indicated that drought resistance traits are scattered in different varieties and among the studied 25 genotypes, we could not find a single specific genotype which has all drought resistance traits at the same time. Furthermore, during the study, only genotype number 7, 21 and 25 showed maximum drought resistance characteristics collectively.

Table2 Correlation coefficient between wheat cultivars

\begin{tabular}{|c|c|c|c|c|c|c|c|c|c|}
\hline & $\mathrm{TF}$ & RDVB & TDVB & TDPB & TDC & TDBXV & DBVBE & $\mathrm{TE}$ & TS \\
\hline TF & 1 & -.088 & -.239 & .205 & .024 & .155 & -.238 & .217 & -0.342 \\
\hline RDVB & & 1 & $.407^{*}$ & $.451^{*}$ & -.012 & -.055 & .292 & -.062 & $0.495^{*}$ \\
\hline TDVB & & & 1 & .276 & -.150 & -.055 & $.580 * *$ & -.109 & $0.566^{* *}$ \\
\hline TDPB & & & & 1 & .340 & -.091 & .244 & .071 & 0.184 \\
\hline TDC & & & & & 1 & -.021 & .124 & .367 & -0.231 \\
\hline TDBXV & & & & & & 1 & .075 & .178 & 0.028 \\
\hline DBVBE & & & & & & & 1 & .056 & $0.591^{* *}$ \\
\hline $\mathrm{TE}$ & & & & & & & & 1 & 0.03 \\
\hline TS & & & & & & & & & 1 \\
\hline
\end{tabular}

"Correlation is significant at the 0.05 level; ${ }^{* *}$ Correlation is significant at the 0.01 level 


\section{References}

Abbasi M, Faghani E, Soghi H, Hosein Khani A (2016) Anatomical Studies of Drought Tolerance Related Traits of 26 Wheat Varieties In Iran. AGROFOR International Journal 1: 130142. DOI: http://dx.doi.org/10.7251/AGRENG1601130A.

Abebe T, Guenzi AC, Martin G, Cushman JC (2003) Tolerance of Mannitol-Accumulating Transgenic Wheat to Water Stress and Salinity. Plant Physiology131: 1748-1755. doi: 10.1104/pp.102.003616.

Adhikary SK, Alam MZ, Haider SA, Paul NK (2007) Leaf anatomical characters in relation to grain yield of wheat (Triticum aestivum L.) cultivars. Journal of Bioscience 15:153-158. doi: 10.3329/jbs.v15i0.2156 Â.

Ashraf M, Harris PJC (2005) Abiotic stresses: Plant resistance through breeding and molecular Approaches. CRC Press Inc., New York.

Bahar B, Yildirim M, Barutcular C, Genc I (2008) Effect of Canopy Temperature Depression on Grain Yield and Yield Components in Bread and Durum Wheat. Notulae Botanicae Horti AgrobotaniciCluj-Napoca 36: 34-37. DOI: http://dx.doi.org/10.15835/nbha36187.

Blum A (1996) Crop responses to drought and the interpretation of adaptation. Plant Growth Regulation 20: 135- 148. doi:10.1007/BF00024010.

Blum A (2011) Drought tolerance - is it a complex trait? Functional Plant Biology 38 : 753-757. DOI: https://doi.org/10.1071/FP11101.

Bohnert HJ, Jensen RG (1996). Strategies for engineering water stress tolerance in plants. Trends in Biotechnology 14: 18-27. DOI: https://doi.org/10.1016/0167-7799(96)80929-2.

Boyer JS (1982) Plant productivity and environments. Science 218: 443-448. DOI: 10.1126/science.218.4571.443.

Drake PL, Froend R, Franks PJ (2013) Smaller, faster stomata: scaling of stomatal size, rate of response, and stomatal conductance. Journal of Experimental Botany 64: 495-505. DOI: https://doi.org/10.1093/jxb/ers347.

Farooq M, Wahid A, Kobayashi N, Fujita D, Basra SMA (2009) Plant drought stress: effects, mechanisms and management. Agronomy for Sustainable Development 29:185-212. doi:10.1051/agro:2008021.

Hansen MA, Hidayat BJ, Mogensen KK, Jeppesen MD, Jørgensen B, Johansen KS, Thygesen LG (2013) Enzyme affinity to cell types in wheat straw (Triticum aestivum L.) before and after hydrothermal pretreatment. Biotechnology for Biofuels 6: 54- 66. DOI: $10.1186 / 1754-6834-6-54$.
Jones MB, Leafe LE, Stiles W (1980) Water stress in field grown perennial ryegrass. II. Its effects on leaf water status, stomatal resistance and leaf morphology. Annals of Applied Biology 96: 103-110. DOI: 10.1111/j.1744-7348.1980.tb04773.x.

Kahrizi D, Maniee M, Mohammadi R, Cheghamirza K (2010) Estimation of genetic parameters related to morpho-agronomic traits of Durum Wheat (Triticum turgidum var. durum). Biharean Biologist 4: 93-97.

Kazmi RH, Khan MQ, Abbasi M (2003) Effect of water stress on the performance of wheat grown under controlled conditions at Rawalakot, Azad Jammu and Kashmir. Sarhad Journal of Agriculture 19: 61-67.

Kulkarni M, Borse T, Chaphalkar S (2008) Mining Anatomical Traits: A Novel Modeling Approach for Increased Water Use Efficiency under Drought Conditions in Plants. Czech Journal of Genetics and Plant Breeding 44: 11-21.

Kulkarni M, Deshpande U (2006) Comparative studies in stem anatomy and morphology in relation to drought tolerance in tomato (Lycopersicon esculentum). American Journal of Plant Physiology 1: 82-88. DOI: 10.3923/ajpp.2006.82.88.

Ludlow MM, Muchow RC (1990) A critical evaluation of traits for improving crop yields in water-limited environments. Advances in Agronomy 43: 107- 153.

Martre P, Durand JL (2001) Quantitative analysis of vasculature in the leaves of Festuca arundinacea (Poaceae): implications for axial water transport. International Journal of Plant Sciences 162:755-766. DOI: https://doi.org/10.1086/320786.

Mitra J (2001) Genetics and genetic improvement of drought resistance in crop plants. Current Science 80: 758-762.

Mujeeb-Kazi A, Gul A, Farooq M, Rizwan S, Ahmad I (2008) Rebirth of synthetic hexaploids with global implications for wheat improvement. Australian Journal of Agricultural Research 59 : 391-398. DOI: https://doi.org/10.1071/AR07226.

Ogbonnaya F, Mujeeb-Kazi A, Kazi A, Lagudah E.L, Bonnett D (2013) Synthetic hexaploid in wheat improvement. Breeding Reviews, John Wiley \& Sons Inc.

Pirayvatlov AS (2001) Relations among yield potential, drought tolerance and stability of yield in bread wheat cultivars under water deficit conditions. Proceedings of the 10th Australian Agronomy Conference, Hobart.

Rebetzke GJ, López-Castañeda C, Botwright TL, Condon AG, Richards RA (2008) Inheritance of coleoptile tiller appearance and size in wheat. Australian Journal of Agricultural Research 59: 863-873. 
Sajjad M, Khan S H, Khan AS (2011) Exploitation of germplasm for grain yield improvement in spring wheat (Triticum aestivum L.). International Journal of Agriculture and Biology 13: 695-700.

Sloane RJ, Patterson RP, Carter TE Jr (1990) Field drought tolerance of soybean plant introduction. Crop Science 30: 118-123.

Teulat B, Borries C, This D (2001) New QTLs identified for plant water status, water-soluble carbohydrate and osmotic adjustment in a barley population grown in a growth-chamber under two water regimes. Theoretical and Applied Genetics 103:161-170. doi: $10.1007 / \mathrm{s} 001220000503$.
Venora G, Calcagno F (1991) Influence of vascular system in Triticum durum Desf. on drought adaptation. Cereal Research Communications 19: 319-326.

Waldern RP, (1982) Introductory crop science. Burgress publishing company, Minneapolis 194.

Zhang J, Wensuo J, Jianchang, Y, Abdelbagi M I (2006) Role of $\mathrm{ABA}$ in integrating plant responses to drought and salt stresses. Field Crops Research 97: 111-119. DOI: https://doi.org/10.1016/j.fcr.2005.08.018. 